\title{
Pengujian Konsistensi, Waktu Adaptasi, Palatabilitas dan Persentase Disintegrasi Ransum Blok Khusus Ternak Sapi Potong Antarpulau
}

\author{
Evaluation of Consistency, Adaptation Time, Palatability and Disintegration Percentage \\ of Feed Block for Interisland Beef Cattle
}

\section{Made Adi Sudarma}

\author{
Program Studi Peternakan Universitas Kristen Wira Wacana Sumba \\ Jl. R. Soeprapto No. 35, Waingapu 87113 \\ Email : adi_dharma17@yahoo.com
}

\begin{abstract}
This study aimed to develop a special feed block for interisland transported cattle and evaluated the animal responses. The feed block had $2 \mathrm{~kg}$ dry matter of weight and contain $16.31 \%$ of crude protein and $9.17 \mathrm{MJ}$ each kilograms dry matter. The reason of high level of protein and energy contain in the feed block are to make sure the interisland beef cattle can take the nutrient requirement even though with low dry matter intake. This experiment, used 3 level of pressure $1000 \mathrm{~N}\left(\mathrm{P}_{10}\right) ; 2000 \mathrm{~N}\left(\mathrm{P}_{20}\right)$ and $3000 \mathrm{~N}\left(\mathrm{P}_{30}\right)$ which had been presented simultaneously to 5 of male Bali cattle with cafetaria feeding method during 5 days. The result showed the feed was easily to be consumption in $\mathrm{P}_{10}$ and $\mathrm{P}_{20}$ compared to $\mathrm{P}_{30}\left(2.174 ; 2.308\right.$ and $0.018 \mathrm{~kg} /$ day respectively). $\mathrm{P}_{20}$ was the best feed of disintegration percentage which hadn't broken easily compared to $\mathrm{P}_{10}(9.64 \%: 24.98 \%)$. It may be conclude that feed blok can be tested as a sole feed for interisland traded cattle to avoid weight loss during quarantine and shipment.
\end{abstract}

Key words : Bali cattle, weight loss, interisland beef cattle, level of pressure

\begin{abstract}
ABSTRAK
Penelitian ini bertujuan untuk mengembangkan ransum blok khusus ternak sapi antarpulau dan mengevaluasi respon ternak sapi potong antarpulau yang mendapatkan ransum blok tersebut. Ransum blok memiliki berat $2 \mathrm{~kg}$ bahan kering serta mengandung PK 16,31\% dan energi 9,17 MJ/kgBK. Ransum blok mengandung level protein dan energi yang tinggi diupayakan agar ternak sapi potong antar pulau dapat memenuhi kebutuhan nutrisinya walaupun hanya mengkonsumsi sebagian dari ransum blok yang disediakan. Penelitian ini menggunakan tiga perlakuan tekanan $1000 \mathrm{~N}\left(\mathrm{P}_{10}\right), 2000 \mathrm{~N}\left(\mathrm{P}_{20}\right)$, dan $3000 \mathrm{~N}\left(\mathrm{P}_{30}\right)$ pada ransum blok yang diberikan pada 5 ekor ternak sapi Bali jantan dengan sistem kafetaria selama 5 hari. Hasil penelitian menunjukkan bahwa $\mathrm{P}_{10}$ dan $\mathrm{P}_{20}$ lebih mudah dikonsumsi dibandingkan $\mathrm{P}_{30}$ (berturut-turut 2,174; 2,308 dan 0,018 kg/24 jam). Hasil terbaik ditunjukkan pada $\mathrm{P}_{20}$ yang memiliki persentase disintegrasi yang tidak mudah hancur dibandingkan $\mathrm{P}_{10}(9,64 \%$ : 24,98\%). Dapat disimpulkan bahwa ransum blok khusus dapat diujicobakan sebagai pakan tunggal untuk ternak sapi antarpulau yang diharapkan mampu menekan penyusutan bobot badan selama masa karantina dan transportasi laut.
\end{abstract}

Kata Kunci : Sapi Bali, penyusutan, sapi potong antarpulau, level tekanan

\section{PENDAHULUAN}

Nusa Tenggara Timur (NTT) merupakan salah satu wilayah sentra produksi ternak sapi potong di Indonesia yang selalu mengirimkan ternak sapinya dengan standar bobot badan di atas $250 \mathrm{~kg}$ setiap tahunnya untuk memenuhi kebutuhan daging di wilayah sentra konsumsi seperti Daerah Khusus Ibukota (DKI) Jakarta, Jawa Barat dan Kalimantan. Namun dalam proses pengiriman tersebut terdapat penyusutan bobot badan ternak sapi antarpulau yang cukup besar. Leopenu et al. (2009) memperlihatkan bahwa terdapat penyusutan bobot badan berlebihan dari ternak sapi yang diantarpulaukan dari NTT ke DKI Jakarta selama masa karantina dan transportasi laut yang dapat mencapai $17 \%$ (rata-rata penyusutan $12,6 \%$ dari bobot badan ternak). Hasil penelitian ini sedikit lebih besar dari 
hasil penelitian Ilham dan Yusdja (2004) yakni tingkat penyusutan ternak selama masa transportasi dari luar pulau Jawa ke sentra konsumsi di Pulau Jawa sebesar 10,5\%.

Penyusutan bobot badan ternak sapi antarpulau yang dikirimkan dari NTT ke daerah tujuan di sentra konsumsi memberikan kerugian yang sangat besar bagi pendapatan daerah maupun peternak. Apabila terjadi penyusutan bobot badan dengan ratarata $12,6 \%$ dari 60.000 ekor ternak sapi yang diantarpulaukan setiap tahunnya dari NTT dengan rata-rata bobot badan minimal $250 \mathrm{~kg}$ maka terdapat penyusutan daging sebesar 1.890 ton bobot hidup yang hilang begitu saja selama masa transportasi. Apabila mengikuti harga daging sapi di Samarinda dengan rata-rata Rp. $41.000 / \mathrm{kg}$ bobot hidup maka terdapat kehilangan pendapatan sebesar 77,49 milyar rupiah per tahunnya.

Pada umumnya ternak yang diantarpulaukan mengalami penyusutan sebagai dampak asupan nutrisi yang diperoleh ternak selama transportasi sangat rendah. Terdapat beberapa faktor yang mempengaruhi rendahnya supply nutrisi oleh ternak selama masa karantina dan transportasi seperti kualitas pakan yang rendah dan tidak sesuai dengan pakan yang biasa dikonsumsi (Leopenu et al., 2009) serta konsumsi pakan dan air yang rendah (Lailogo, 1989; Ika, 1983).

Rumput alam kering dengan kualitas rendah (standing hay) maupun jerami padi merupakan pakan utama yang sering diberikan pada ternak sapi potong yang diantarpulaukan selama masa karantina dan transportasi laut (Leopenu, 2009; Lailogo, 1989; Ika, 1983). Jenis pakan ini memiliki nilai nutrisi yang rendah dan dalam penggunaannya sebagai pakan tunggal tidak mampu memenuhi kebutuhan nutrisi ternak selama masa transportasi. Selain itu, jenis pakan tersebut juga bersifat bulky sehingga tidak praktis dari segi manajemen seperti penyediaan, penyimpanan dan pemberian pakan pada ternak. Bahkan penggunaan standing hay dapat menyebabkan kebakaran karena mudah terbakar selama masa penyimpanan.

Salah satu cara yang dapat ditempuh dalam mengatasi permasalahan penyusutan bobot badan ternak selama masa transportasi tersebut adalah dengan menyediakan ransum yang sesuai dengan kebutuhan nutrisi ternak (Achmadi, 2010; Deblitz et al., 2011) serta mampu menurunkan stres pada ternak dengan biaya yang ekonomis menggunakan bahan pakan lokal yang tersedia melimpah di NTT, murah dan mudah diperoleh, serta aman dan sudah biasa dikonsumsi oleh ternak. Selain itu, ransum tersebut perlu didesain dalam bentuk dan tingkat konsistensi tertentu sehingga memudahkan dalam manajemen pemberian ransum dan cukup disukai oleh ternak selama masa karantina dan transportasi ternak.

\section{MATERI DAN METODE}

Materi yang digunakan dalam penelitian ini adalah 5 ekor ternak sapi Bali jantan dengan rata-rata bobot badan ternak $161,9 \pm 21,3 \mathrm{~kg}$. Bahan yang digunakan dalam penelitian ini berupa rumput kering, tepung lamtoro, tepung putak, tepung ikan, urea dan mineral. Adapun alat yang digunakan dalam penelitian ini berupa alat pressuremerk ELE International dengan kapasitas maksimum 3000 N (skala 1 - 30), timbangan digital, ember, bak plastik, cetakan besi, terpal dan stopwatch. Adapun kandungan nutrisi bahan penyusun ransum blok dapat dilihat pada Tabel 1. berikut ini.

Tabel 1. Kandungan nutrisi beberapa bahan penyusun ransum blok

\begin{tabular}{llllllllll}
\hline \multirow{2}{*}{$\begin{array}{l}\text { Bahan } \\
\text { pakan }\end{array}$} & BK & BO & PK & LK & SK & CHO & \multicolumn{2}{c}{ BETN } & \multicolumn{2}{c}{ Gross Energy } \\
\cline { 2 - 9 } & $(\%)$ & $(\% \mathrm{BK})$ & $(\% \mathrm{BK})$ & $(\% \mathrm{BK})$ & $(\% \mathrm{BK})$ & $(\% \mathrm{BK})$ & $(\% \mathrm{BK})$ & $\mathrm{MJ} / \mathrm{kg} \mathrm{BK}$ & $\mathrm{Kkal} / \mathrm{kg} \mathrm{BK}$ \\
\hline Rumput & 90,53 & 91,48 & 2,61 & 1,30 & 32,9 & 87,57 & 54,67 & 16,22 & $3.863,02$ \\
Putak & 87,01 & 97,78 & 4,01 & 3,11 & 3,28 & 90,66 & 87,39 & 17,72 & $4.218,17$ \\
Lamtoro & 89,19 & 92,36 & 22,41 & 6,56 & 13,50 & 63,39 & 49,88 & 18,64 & $4.437,20$ \\
Ikan & 92,95 & 98,40 & 72,11 & 5,60 & 0,11 & 20,69 & 20,58 & 22,97 & $5.468,26$ \\
\hline
\end{tabular}

Sumber : hasil analisis Laboratorium Kimia Pakan, Fakultas Peternakan, Undana (2014) 
Tabel 2. Kandungan nutrisi ransum blok

\begin{tabular}{llllll}
\hline \multirow{2}{*}{ Bahan pakan } & $\begin{array}{l}\text { Komposisi } \\
\%\end{array}$ & $\begin{array}{l}\text { BK } \\
\%\end{array}$ & $\begin{array}{l}\text { BO } \\
\% \text { BK }\end{array}$ & $\begin{array}{l}\text { PK } \\
\text { gram }\end{array}$ & $\begin{array}{l}\text { Energi Metabolis* } \\
\text { MJ/Kg BK }\end{array}$ \\
\hline Rumput kering & 40 & 36,21 & 36,59 & 94,51 & 3,856 \\
Putak & 20 & 17,40 & 19,55 & 69,78 & 1,929 \\
Lamtoro & 30 & 26,75 & 27,70 & 599,62 & 2,897 \\
Tepung ikan & 2,5 & 2,32 & 2,46 & 167,56 & 0,242 \\
Urea & 2,5 & 2,48 & 2,50 & 699,60 & 0,245 \\
Mineral mix & 5 & 5,00 & & & \\
\hline Total & 100 & 90,18 & 88,82 & 1631,09 & 9,17 \\
\hline
\end{tabular}

Keterangan DE $=\{[11,78+(0,0654 \mathrm{x} \% \mathrm{PK})]+[0,0065 \mathrm{x} \% \mathrm{LK}]-[0,0414 \mathrm{x} \% \mathrm{SK}]-[0,118 \mathrm{x} \% \mathrm{abu}]\} ; \mathrm{ME}=0,82 \mathrm{xDE}(\mathrm{NRC}, 2000)$

Rancangan percobaan yang digunakan dalam penelitian ini adalah Rancangan Acak Lengkap untuk menguji perbedaan diantara 3 level tekanan ransum yang diujicobakan. Ketiga perlakuan tersebut disajikan secara bersama-sama pada 5 ekor ternak dengan sistem "cafeteria feeding" dalam kandang individu selama 5 hari berturut-turut tanpa dilakukan penyesuaian terlebih dahulu. Adapun perlakuan tekanan yang diberikan adalah $\mathrm{P}_{10}=$ Blok yang diberi tekanan sebesar $1000 \mathrm{~N} ; \mathrm{P}_{20}=$ Blok yang diberi tekanan sebesar $2000 \mathrm{~N} ; \mathrm{P}_{30}=$ Blok yang diberi tekanan sebesar $3000 \mathrm{~N}$. Parameter penelitian yang diamati berupa tingkat konsistensi ransum blok, waktu adaptasi, palatabilitas dan persentase disintegrasi. Data yang diperoleh dianalisis dengan sidik ragam ANOVA, di mana perbedaan antara perlakuan dinyatakan berbeda nyata pada nilai $\mathrm{P}<0,05$. Data dianalisis menggunakan software SPSS 18,0 for windows.

\section{HASIL DAN PEMBAHASAN}

\section{Perekayasaan ransum blok khusus ternak sapi antarpulau}

Ransum blok khusus ternak sapi antarpulau merupakan produk pakan ternak yang diformulasikan khusus untuk menekan tingkat penyusutan berlebih pada ternak sapi potong yang diantarpulaukan. Ransum didesain berbentuk blok/kotak persegi (20x20x30 cm) dengan bobot $2 \mathrm{~kg} /$ blok dan terdiri dari bahan pakan yang murah dan banyak terdapat di daerah NTT (Tabel 2) serta tinggi akan nutrisi dan dapat disimpan dalam waktu lama. Hal ini seturut dengan pernyataan Trisyulianti et al. (2003) bahwa salah satu manfaat pengolahan pakan berbentuk blok adalah untuk menjaga keseimbangan ketersediaan bahan hijauan pakan sepanjang tahun serta dapat meningkatkan palatabilitas.

Ransum didesain berbentuk kotak persegi yang berguna untuk memudahkan ternak dalam mengkonsumsi ransum serta tidak berguling/bergeser ketika ditempatkan di tempat makan terutama di atas kapal saat transportasi laut. Selain itu, desain ransum yang berbentuk kotak persegi juga memudahkan dalam manajemen penyimpanan dan pengangkutan pakan serta dapat menghemat ruangan penyimpanan pakan.

Ransum blok terdiri dari beberapa jenis bahan pakan lokal seperti rumput alam kering, hay daun lamtoro, tepung putak, tepung ikan, serta penambahan urea dan mineral untuk menyediakan kandungan nutrisi ransum yang baik bagi ternak sapi yang akan diantarpulaukan. Dalam ransum ini, penggunaan bahan pakan putak sekaligus dimanfaatkan sebagai bahan perekat blok pengganti bahan kanji di mana tepung putak memiliki sifat lengket apabila dipanaskan dalam air serta sebagai sumber energi yang sangat dibutuhkan ternak terutama ternak sapi Bali. Menurut Biri et al. (1998) menyatakan bahwa putak sebagai penghasil karbohidrat mampu memberikan pertambahan bobot badan yang lebih tinggi (425 gr/ekor/hari) pada campuran pakan rumput lapangan, putak dan biji kapuk dibandingkan pakan tanpa putak (364 gr/ekor/hari) maupun pakan tanpa putak dan biji kapuk (171 gr/ekor/hari) karena adanya nitrogen dari biji kapas dan karbohidrat 
sebagai sumber energi dari putak memungkinkan mikro organisme rumen bekerja secara efisien.

Widiarti (2008) menyatakan bahwa tingkat tekanan pada wafer dapat bervariasi seperti $12 \mathrm{~kg} / \mathrm{cm}^{2}$ hingga $300 \mathrm{~kg} / \mathrm{cm}^{2}$ tergantung jenis bahan pakan dan komposisinya dalam ransum. Dalam penelitian ini, diberikan 3 macam jenis tingkatan tekanan yakni $1000 \mathrm{~N} \quad(0,29$ $\left.\mathrm{kg} / \mathrm{cm}^{2}\right) ; 2000 \mathrm{~N}\left(0,58 \mathrm{~kg} / \mathrm{cm}^{2}\right)$; dan $3000 \mathrm{~N}$ $\left(0,86 \mathrm{~kg} / \mathrm{cm}^{2}\right)$ di mana pada uji coba skala Laboratorium didapati bahwa jenis bahan pakan dan komposisi ransumsudah cukup mengalami pemadatan tinggi pada 0,86 $\mathrm{kg} / \mathrm{cm}^{2}$. Adapun pengaruh level tingkatan tekanan dalam proses pemadatan blok yang diujicobakan pada 5 ekor ternak percobaan dapat dilihat pada Tabel 3.

\section{Pengaruh level tekanan terhadap tingkat palatabilitas ransum blok}

Palatabilitas dengan sistem kafetaria (pakan disajikan bersamaan kepada ternak sehingga ternak bebas memilih pakan yang akan dikonsumsi) yang dilakukan pada penelitian ini digunakan untuk mengetahui seberapa besar tingkat kesukaan ternak sapi Bali terhadap pakan ransum blok. Palatabilitas atau tingkat kesukaan ternak pada ransum dapat dilihat dari waktu yang dibutuhkan ternak untuk mulai mengkonsumsi blok dan jumlah waktu konsumsi selama 3 jam sejak disajikan. Pada umumnya ternak sapi cukup menyukai ransum ini di mana terlihat tidak lebih dari 1 hari saat disajikan ternak sapi langsung mencium dan mengkonsumsi pakan tersebut.
Adanya tingkat waktu adaptasi yang cukup baik dari ransum ini disebabkan oleh penggunaan bahan pakan yang sudah biasa dikonsumsi oleh ternak sapi Bali di NTT seperti rumput alam kering oleh ternak sapi Bali yang biasa digembalakan dan lamtoro maupun putak pada sapi Bali yang dipelihara dengan sistem paron. Hal ini sesuai dengan pernyataan Leopenu et al. (2009) yang menyatakan bahwa ternak-ternak yang berasal dari sistem pemeliharaan dengan cara digembala yang umumnya sudah terbiasa mengkonsumsi rumput lapangan dengan kualitas yang berfluktuasi menurut musim akan lebih dapat menyesuaikan dengan ketersediaan ransum di karantina hewan yang tidak jauh berbeda seperti rumput kering sehingga memiliki tingkat penyusutan yang lebih rendah dibandingkan dengan ternak dengan sistem pemeliharaan paron. Lebih lanjut dijelaskan oleh Leopenu et al. (2009) bahwa tingginya tingkat penyusutan bobot badan pada ternak dengan sistem pemeliharaan paron dikarenakan ternak sudah terbiasa mendapatkan pakan hijauan segar (umumnya legume) dan tidak terbiasa mengkonsumsi rumput kering/jerami.

Ransum blok juga menggunakan pakan yang tidak dibuat dalam bentuk tepung melainkan cacahan sehingga memberikan kesempatan bagi ternak untuk mengetahui/ melihat bahwa ransum blok tersebut bukanlah pakan baru bagi mereka. Adanya bau harum khas dari pakan juga memberikan nilai lebih dari ransum blok ini karena ternak sapi Bali sebelum mengkonsumsi pakan, pasti akan mencium cium terlebih dahulu pakan tersebut.

Tabel 3. Pengaruh level tekanan rendah $\left(\mathrm{P}_{10}\right)$, sedang $\left(\mathrm{P}_{20}\right)$ dan tinggi $\left(\mathrm{P}_{30}\right)$ terhadap waktu adaptasi, waktu konsumsi, persentase disintegrasi dan tingkat konsumsi total ransum blok oleh ternak sapi penggemukan

\begin{tabular}{|c|c|c|c|c|c|}
\hline \multirow{2}{*}{ Parameter } & \multicolumn{3}{|c|}{ Ransum Perlakuan } & \multirow{2}{*}{ SEM } & \multirow{2}{*}{$P$ value } \\
\hline & $\mathrm{P}_{10}$ & $\mathrm{P}_{20}$ & $\mathrm{P}_{30}$ & & \\
\hline $\begin{array}{l}\text { Waktu yang dibutuhkan ternak untuk mulai } \\
\text { mengkonsumsi blok (Menit) }\end{array}$ & $3,12^{\mathrm{a}}$ & $5,96^{\mathrm{b}}$ & $18,44^{\mathrm{c}}$ & 0,751 & $<0,001$ \\
\hline Total waktu konsumsi (Menit) * & $81,8^{a}$ & $60,2^{b}$ & $4,4^{\mathrm{c}}$ & 1,112 & $<0,001$ \\
\hline Persentase disintegrasi $(\%)$ & $24,98^{\mathrm{a}}$ & $9,64^{\mathrm{b}}$ & $0,51^{\mathrm{c}}$ & 0,455 & $<0,001$ \\
\hline Konsumsi total (kg/24 jam) & $2,174^{\mathrm{a}}$ & $2,308^{a}$ & $0,018^{b}$ & 0,066 & $<0,001$ \\
\hline
\end{tabular}




\section{Waktu yang dibutuhkan ternak untuk mulai mengkonsumsi ransum}

Waktu yang dibutuhkan ternak untuk mulai mengkonsumsi ransum merupakan salah satu faktor penilaian penting dalam menilai kualitas suatu pakan. Semakin cepat ternak mengkonsumsi pakan tersebut maka akan semakin baik nilai dari pakan tersebut. Pada perlakuan tekanan ransum ini, terdapat perbedaan yang nyata antara ketiga perlakuan $\mathrm{P}_{10}, \mathrm{P}_{20}$ dan $\mathrm{P}_{30}$ di mana perlakuan $\mathrm{P}_{10}$ memiliki tingkat waktu untuk mulai mengkonsumsi yang paling rendah $(3,12$ menit) diikuti oleh perlakuan $\mathrm{P}_{20}$ (5,96 menit) dan perlakuan $\mathrm{P}_{30}$ (18,44 menit). Namun, semua jenis perlakuan tekanan memperlihatkan daya adaptasi oleh ternak untuk mulai mengkonsumsi yang cukup baik yakni kurang dari 1 hari. Hal ini mengindikasikan bahwa ransum blok cukup disukai oleh ternak sapi Bali.

Pada saat pemberian pakan, ternak pada awalnya mulai mencium dan menjilat pakan blok yang diberikan. Semua jenis pakan blok dicium satu per satu namun hampir semua ternak mulai merenggut ransum $\mathrm{P}_{10}$ dan $\mathrm{P}_{20}$ setelah semua ransum dicium. Untuk ransum $\mathrm{P}_{30}$, ternak berusaha merenggut tapi tidak banyak yang berhasil didapatkan oleh lidah ternak sehingga ternak kembali merenggut ransum $\mathrm{P}_{10}$ dan $\mathrm{P}_{20}$.

\section{Total waktu konsumsi}

Dalam sistem kafetaria, total waktu konsumsi ternak selama selang waktu tertentu sejak diberikan dapat mengindikasikan nilai palatabilitas dari beberapa jenis ransum tersebut. Ransum dengan nilai total waktu konsumsi tertinggi mengindikasikan nilai palatabilitas ransum yang lebih tinggi dibanding ransum lainnya.

Table 3. memperlihatkan bahwa terdapat perbedaan yang nyata dalam hal total waktu konsumsi ternak selama 3 jam sejak diberikan antara perlakuan $\mathrm{P}_{10}, \mathrm{P}_{20}$ dan $\mathrm{P}_{30}$ berturut-turut 81,8 menit, 60,2 menit dan 0,15 menit. Hasil penelitian ini memperlihatkan bahwa ransum blok dengan perlakuan tekanan $1000 \mathrm{~N}$ secara nyata memberikan nilai palatabilitas yang lebih tinggi dibandingkan perlakuan $\mathrm{P}_{20}$ maupun $\mathrm{P}_{30}$. Adapun waktu konsumsi ransum $\mathrm{P}_{10}$ terbanyak pada awal penyajian hingga 60 sampai 90 menit setelah disajikan, sedangkan waktu konsumsi ransum $\mathrm{P}_{20}$ lebih mendominasi pada 90 sampai 150 menit setelah disajikan. Hal ini dimungkinkan karena ransum $\mathrm{P}_{10}$ lebih mudah direnggut oleh ternak dibandingkan ransum lainnya dan ketika ransum sudah banyak terlepas dan tercecer di dalam bak pakan maka ternak mulai merenggut ransum $\mathrm{P}_{20}$ yang belum banyak tercecer.

\section{Pengaruh level tekanan terhadap tingkat konsumsi ransum blok}

Retnani et al. (2009) menyatakan bahwa tingkat palatabilitas suatu ransum dapat juga diketahui dengan menghitung total konsumsi bahan kering ransum dalam satu hari yang diberikan dengan sistem cafeteria feeding. Secara umum hasil penelitian menunjukkan bahwa ransum $\mathrm{P}_{10}$ dan $\mathrm{P}_{20}$ tidak berbeda nyata dalam hal total konsumsi selama 24 jam sejak disajikan yakni berturutturut $2,174 \mathrm{~kg}(48,46 \%)$ dan $2,308 \mathrm{~kg}$ $(51,12 \%)$. Hasil penelitian ini memperlihatkan bahwa pemberian tekanan hingga $2000 \mathrm{~N}$ pada perlakuan $\mathrm{P}_{20}$ masih dapat dikonsumsi dengan baik oleh ternak. Jika level tekanan pada ransum blok ditingkatkan hingga $3000 \mathrm{~N} \quad\left(\mathrm{P}_{10}\right)$ maka tingkat konsumsi ransum akan menurun menjadi $0,018 \mathrm{~kg} / 24$ jam $(0,42 \%)$ di mana ternak mengalami kesulitan dalam proses perenggutan /pelepasan bahan pakan dari blok ransum.

Rata-rata konsumsi bahan kering ternak terhadap ransum blok adalah sebesar $2,51 \pm 0,13 \%$ dari bobot badan $(161,9 \mathrm{~kg})$. Berdasarkan level konsumsi bahan kering ini, diketahui bahwa ransum blok mampu menyediakan energi metabolis sebesar 37,26 $\mathrm{MJ} /$ ekor/hari atau sebesar $0,82 \mathrm{MJ} / \mathrm{kgbb}^{0,75}$. Kearl (1982) menyatakan bahwa ternak sapi dengan bobot badan $200 \mathrm{~kg}$ membutuhkan energi metabolis untuk kebutuhan hidup pokok selama 24 jam minimal sebesar 26,36 $\mathrm{MJ} /$ ekor/hari $\left(0,49 \mathrm{MJ} / \mathrm{kgbb}^{0,75}\right)$. Potensi konsumsi energi metabolis dari ransum ini 
cukup besar di mana jauh melebihi kebutuhan hidup pokok ternak dengan bobot badan $200 \mathrm{~kg}$ sehingga ternak tersebut cukup mengkonsumsi ransum sebanyak $1,44 \%$ dari bobot badan untuk memenuhi kebutuhan hidup pokoknya. Selain itu, potensi level konsumsi ransum blok sebesar $2,51 \%$ dari bobot badan juga mampu menyediakan kebutuhan energi metabolis untuk ternak dengan bobot badan $300 \mathrm{~kg}$ yang mana ternak membutuhkan energi metabolis sebesar 35,56 MJ/ekor/hari (0,49 MJ $/ \mathrm{kgbb}^{0,75}$ ).

Ransum blokmemiliki potensi yang baik untuk dijadikan sebagai pakan utama ternak sapi Bali yang pada umumnya memiliki tingkat konsumsi pakan sebesar 2$3 \%$ dari bobot badan ternak setiap harinya. Ransum blok ini sudah diujicobakan juga pada ternak sapi potong antar pulau selama masa karantina dan transportasi laut dari Kupang ke Samarinda dimana terdapat perbedaan secara nyata $(<0,01)$ antara konsumsi ransum blok $1,31 \%$ dari bobot badan dibandingkan dengan pakan kontrol $0,68 \%$ dari bobot badan (Sudarma et al., 2015). Hasil penelitian konsumsi pakan ini juga tidak jauh berbeda dengan hasil penelitian penggemukan pada sapi Bali yang mengkonsumsi pakan rumput alam sebesar 2,6\%, namun masih lebih rendah dari konsumsi ransum rumput alam ditambah turi (0,5\% dari $\mathrm{BB})$ mencapai $3 \%$ bahan kering dari bobot badan ternak setiap harinya (Panjaitan dan Prisdiminggo, 2013). Hasil penelitian ini juga memperlihatkan konsumsi bahan kering sapi Bali terhadap ransum blok yang jauh lebih rendah dari ternak pedet $\mathrm{FH}$ di mana wafer ransum komplit dari pucuk dan ampas tebu mampu dikonsumsi oleh pedet FH mencapai 3,9\% (Retnani et al., 2009) dan 3,5\% (Widiarti, 2008).

\section{Pengaruh level tekanan terhadap persentase disintegrasi ransum blok}

Salah satu tujuan pembuatan pakan ternak sapi antarpulau berbentuk blok adalah untuk memudahkan dalam proses manajemen pemberian pakan dan konsumsi oleh ternak selama berada di atas kapal dibandingkan pakan berbentuk tepung maupun pellet. Pakan berbentuk tepung maupun pellet diperkirakan akan cukup rumit dalam proses manajemen pemberian pakan karena pakan tersebut akan mudah terbuang saat kapal bergoyang yang mengakibatkan ternak sulit mengkonsumsi pakan tersebut. Selain itu penggunaan pakan berbentuk tepung dan pellet selama masa transportasi laut juga membutuhkan tempat makanan khusus ternak di atas kapal serta membutuhkan tambahan waktu bagi kleder untuk menghitung jumlah pakan yang harus diberikan setiap harinya. Oleh karena itu, penggunaan pakan ternak sapi antarpulau dirancang berbentuk blok yang lebih stabil saat kapal bergoyang dan menghemat waktu petugas kapal saat memberi makan ternak. Namun, tingkat persentase disintegrasi dari blok ransum harus diperhatikan untuk mengoptimalkan rendahnya jumlah pakan yang akan terlepas setelah direnggut oleh ternak.

Persentase disintegrasi merupakan jumlah dari bahan pakan yang sudah terlepas dari blok pakan yang tidak dikonsumsi oleh ternak. Semakin tinggi persentase disintegrasi menunjukkan bahwa semakin mudahnya pakan tersebut terlepas dari blok pakan dan juga ketertarikan ternak akan pakan tersebut. Dari hasil uji coba perlakuan tekanan, menunjukkan bahwa terdapat perbedaan yang nyata antara perlakuan $\mathrm{P}_{10}$; $\mathrm{P}_{20}$ dan $\mathrm{P}_{30}$ di mana perlakuan $\mathrm{P}_{30}$ memiliki tingkat persentase disintegrasi yang sangat rendah yakni $0,51 \pm 0,63 \%$ sedangkan $\mathrm{P}_{10}$ memiliki persentase disintegrasi yang paling tinggi $24,98 \pm 1,92 \%$. Hal ini menunjukkan bahwa semakin tinggi tingkat tekanan yang diberikan maka akan semakin kecil persentase disintegrasinya dan memudahkan dalam manajemen penyimpanan dan transportasi. Hal ini sejalan dengan pernyataan Trisyulianti et al. (2003) yang menyatakan bahwa wafer pakan yang memiliki kerapatan tinggi akan memberikan tekstur yang padat dan keras sehingga mudah dalam penyimpanan dan transportasi dan diperkirakan lebih tahan lama dalam penyimpanan. 
Berdasarkan nilai persentase disintegrasi, perlakuan $\mathrm{P}_{10}$ menunjukkan bahwa pakan blok tersebut paling mudah terlepas, cukup disukai dan mudah direnggut/dikonsumsi oleh ternak. Namun hal ini juga mengindikasikan bahwa pakan tersebut mudah tercecer sehingga terdapat banyak pakan yang sudah terlepas dan belum dikonsumsi ternak. Pada perlakuan $\mathrm{P}_{20}$ menunjukkan bahwa juga terdapat nilai persentase disintegrasi yang cukup besar yakni $9,64 \pm 2,29 \%$ yang menunjukkan bahwa ternak cukup tertarik pada kelembutan (tekstur sedang) dari pakan perlakuan tekanan ini. Selain itu, hal ini juga mengindikasikan bahwa pakan tersebut tidak mudah tercecer sehingga masih cukup banyak pakan yang belum dikonsumsi yang masih berbentuk blok. Pada perlakuan $\mathrm{P}_{30}$ manunjukkan bahwa terdapat nilai persentase disintegrasi yang sangat kecil yang berarti pakan dalam blok tersebut tidak mudah terlepas dan tidak mudah direnggut oleh ternak namun mudah ditransportasikan. Hal ini mengindikasikan bahwa pakan tersebut tidak cocok sebagai pakan blok walaupun baik dalam hal transportasi dan penyimpanan karena sangat rendahnya tingkat konsumsi oleh ternak.

\section{Pengaruh konsistensi ransum blok terhadap palatabilitas dan manajemen ransum}

Konsistensi merupakan salah satu hal yang cukup penting diperhatikan dalam pembuatan blok karena sangat berpengaruh terhadap palatabilitas, tingkat konsumsi dan manajemen penyimpanan blok pakan. Trisyulianti et al. (2003) menyatakan bahwa wafer pakan yang memiliki kerapatan tinggi akan memberikan tekstur yang padat dan keras sehingga mudah dalam penanganan baik penyimpanan dan goncangan pada saat transportasi dan diperkirakan akan lebih lama dalam penyimpanan. Lebih lanjut dikemukakan oleh Trisyulianti et al. (2003) bahwa pakan dengan kerapatan yang rendah akan memperlihatkan bentuk yang tidak padat dan tekstur yang lebih lunak serta berongga sehingga hanya akan bertahan dalam beberapa waktu saja. Sebaliknya, Jayusmar (2000) menyatakan bahwa pakan dengan kerapatan rendah akan memberikan nilai palatabilitas yang lebih tinggi bagi ternak dibandingkan pakan dengan kerapatan tinggi.

Berdasarkan pengamatan konsistensi pada penelitian ini, tekanan $2000 \mathrm{~N}\left(\mathrm{P}_{20}\right)$ merupakan perlakuan yang terbaik karena memiliki tingkat kerapatan sedang yang mudah dikonsumsi oleh ternak namun masih tetap utuh/tidak mudah hancur ketika dikonsumsi. Sedangkan perlakuan lainnya yakni $\mathrm{P}_{10}(1000 \mathrm{~N})$ yang memiliki kerapatan rendah mampu memberikan hasil yang maksimal dalam hal mudah dikonsumsi oleh ternak namun sangat mudah hancur dan tidak bertahan lama. Perlakuan $\mathrm{P}_{30}$ yang memiliki kerapatan tinggi mampu memberikan hasil maksimal dalam hal mudah ditransportasikan namun sulit untuk dikonsumsi oleh ternak karena keras sehingga tidak mudah direnggut oleh ternak.

Tingkat konsistensi blok pakan juga dapat dipengaruhi oleh lama penyimpanan. Menurut Retnani et al. (2009) pada penelitian pembuatan wafer ampas tebu, lama penyimpanan berpengaruh nyata terhadap semua tingkat kerapatan wafer dimana ratarata pada penyimpanan 0 minggu memiliki kerapatan $0,68 \pm 0,27 \mathrm{~g} / \mathrm{cm}^{3}$ sedangkan lama penyimpanan 2 minggu memiliki kerapatan $0,53 \pm 0,06 \mathrm{~g} / \mathrm{cm}^{3}$; akan tetapi kerapatan tidak berpengaruh lagi hingga minggu ke enam dengan kerapatan wafer 0,52 $\pm 0,05$ $\mathrm{g} / \mathrm{cm}^{3}$ yang lebih disebabkan oleh faktor kelembaban yang relatif tinggi sehingga cairan terkondensasi pada permukaan bahan sehingga permukaan bahan menjadi basah dan sangat kondusif untuk pertumbuhan dan kerusakan mikrobial. Oleh karena itu, untuk menjaga konsistensi pakan blok perlu memperhatikan kelembaban tempat penyimpanan agar pakan tidak mengalami kerusakan terutama kerusakan mikrobial. Pada penelitian ini semua pakan blok di simpan di tempat yang kering dan tidak lembab.

Dalam proses produksi ransum blok, penjemuran/ pengeringan ransum merupakan 
salah satu proses produksi yang sangat penting diperhatikan. Proses pengeringan ransum yang tidak optimal (disebabkan oleh faktor cuaca) akan mengakibatkan terjadinya pertumbuhan jamur yang tumbuh di dalam ransum tersebut. Jamur yang tumbuh tersebut akan tetap ada walaupun ransum sudah di jemur ulang (setelah proses pengepresan ransum terkena hujan/ tidak langsung mendapat sinar matahari selama 3 hari berturut-turut). Indikator ransum sudah ditumbuhi jamur adalah adanya warna keputihan pada ransum terutama pada bagian dalam (tengah) ransum blok. Adanya pertumbuhan jamur pada ransum yang tidak optimal dalam proses penjemuran dimungkinkan disebabkan oleh adanya penggunaan putak yang merupakan sumber energi dan perekat ransum blok di mana putak yang telah dicampurkan dengan air panas akan mengental dan menghasilkan sumber energi siap pakai seperti glukosa yang sangat disukai oleh jamur untuk bertumbuh.

\section{KESIMPULAN}

Ransum blok dengan tekanan $2000 \mathrm{~N}$ memiliki tingkat palatabilitas yang lebih tinggi dibandingkan tekanan $3000 \mathrm{~N}$ dan memiliki nilai persentase disintegrasi yang tidak mudah hancur dibandingkan tekanan $1000 \mathrm{~N}$ sehingga cukup disukai dan mudah dikonsumsi oleh ternak serta mempermudah dalam proses manajemen penyimpanan dan transportasi ransum untuk ternak sapi potong antarpulau.

\section{SARAN}

Dibutuhkan penelitian lebih lanjut dalam pengembangan ransum blok dalam tingkatan nilai dan komposisi nutrisi maupun jenis pakan serta cara penyimpanan yang baik sehingga diperoleh ransum yang benarbenar mampu mengatasi masalah penyusutan bobot badan ternak sapi antarpulau dan juga dapat disimpan dalam jangka waktu yang lebih lama.

\section{DAFTAR PUSTAKA}

Achmadi, A.A. 2010. Pengaruh pakan padat gizi terhadap tingkat dehidrasi ternak sapi bali yang ditransportasikan dari Sulawesi Selatan ke Kalimantan Selatan. Skripsi. Fakultas Sains dan Teknologi. Universitas Islam Negeri Alauddin. Makasar.

Biri, J., D. Pasambe dan A. Darmawidah. 1998. Strategi pemanfaatan biji kapas sebagai pakan ternak Sapi Bali. Seminar Nasional Peternakan dan Veteriner.pp. 391-393.

Deblitz, C., T. Kristedi, P.U. Hadi, J. Triastono, K. Puspadi and Nasrullah. 2011. Benchmarking the beef supply chain in eastern Indonesia. Final report. Aciar. Australia.

Ika, S.1983. Penyusutan bobot badan sapi bali jantan selama transportasi trayek Kupang - Jakarta. Skripsi. Fakultas Peternakan Universitas Nusa Cendana. Kupang.

Ilham, N. dan Y. Yusdja. 2004. Sistem tranportasi perdagangan ternak sapi dan implikasi kebijakan di Indonesia. Analisis Kebijakan Pertanian, 2(1): $37-53$.

Jayusmar. 2000. Pengaruh suhu dan tekanan pengempaan terhadap sifat fisik wafer ransum komplit dari limbah pertanian sumber serat dan leguminosa untuk ternak ruminansia. Skripsi. Fakultas Peternakan Institut Pertanian Bogor. Bogor.

Kearl, L. C. 1982. Nutrient requirements of ruminants in developing countries. International Feedstuffs Institute. Utah Agricultural Experiment Station. Utah State University. Logan,Utah USA.

Lailogo, O.T. 1989. Pengaruh lama penampungan di karantina hewan Tenau Kupang terhadap berat badan 
sapi bali sistem pemeliharaan ekstensif. Skripsi. Fakultas Peternakan Universitas Nusa Cendana. Kupang.

Leopenu, C., I. G. N. Jelantik, J. Jermias dan D. Tulle. 2009. Penyusutan berat badan sapi bali asal timor yang diantarpulaukan ke DKI Jakarta. JITP, 3(3): 629-636.

Panjaitan, T. dan Prisdiminggo. 2013. Penggunaan legume pohon turi (Sesbania grandiflora) sebagai pakan sapi penggemukan di Pulau Lombok. Prosiding. Ekspose dan Seminar Nasional Inovasi Pertanian Ramah Lingkungan, Makassar. hlm. 31-36.

Retnani, Y., W. Widiarti, I. Amiroh, L. Herawati dan K.B. Satoto. 2009. Daya simpan dan palatabilitas wafer ransum komplit pucuk dan ampas tebu untuk sapi pedet. Media Peternakan, 32 (2) : 130-136.
Sudarma, I. M. A., M. L. Mullik, and T. O. D. Dato. 2015. Weight loss of interisland transported cattle from kupang is reduced by feeding high proteinmineral mix block during quarantine and sea transportation. Proceeding of the 3 rd International Seminar on Animal Industry, Bogor. pp 367-370.

Trisyulianti, E., Suryahadi dan V.N. Rakhma. 2003. Pengaruh penggunaan molases dan tepung gaplek sebagai bahan perekat terhadap sifat fisik wafer ransum komplit. Media Peternakan 26 (2) :35-40.

Widiarti, W. 2008. Uji sifat fisik dan palatabilitas ransum komplit wafer pucuk dan ampas tebu untuk Pedet Sapi Fries Holland. Skripsi. Fakultas Peternakan Institut Pertanain Bogor. Bogor. 